\title{
Correction to: Environmental Integrants Affecting the Spreadability of SARS-CoV-2
}

\author{
Muhammad Torequl Islam ${ }^{1}$ (i)
}

Published online: 6 May 2021

(c) Springer Science+Business Media, LLC, part of Springer Nature 2021

\section{Correction to: \\ Food and Environmental Virology (2020) 12:278-279 \\ https://doi.org/10.1007/s12560-020-09435-z}

The original version of this article unfortunately contained a mistake. The title was incorrect. SARS-CoV-12 in the title should read as SARS-CoV-2.

Publisher's Note Springer Nature remains neutral with regard to jurisdictional claims in published maps and institutional affiliations.

The original article can be found online at https://doi.org/10.1007/ s12560-020-09435-z.

Muhammad Torequl Islam

dmt.islam@bsmrstu.edu.bd

1 Department of Pharmacy, Life Science Faculty,

Bangabandhu Sheikh Mujibur Rahman Science

and Technology University, Gopalganj 8100, Bangladesh 